\title{
Optimasi Biaya Pengiriman Buah Kelapa Sawit (Studi Kasus PT. Agro Muko)
}

\author{
Ramli Murgani \\ Program Studi Teknik Indutri, Universitas Indraprasta PGRI, Jakarta \\ E-Mail: ramli.gani@gmail.com
}

\begin{abstract}
Abstrak - PT. Agro Muko adalah perusahaan perkebunan kelapa sawit dan melakukan pengiriman buah kelapa sawit dari perkebunan di tiga tempat yaitu Talang Petai Estate, Sei Kiang Estate, dan Tanah Rekah Estate. Dari ketiga lokasi ini akan melakukan pengiriman buah kelapa sawit ke beberapa pabrik yaitu, Muko-Muko, Bunga Tanjung, Air Bikuk, dan Air Hitam.Pengiriman buah kelapa sawit menggunakan alat transportasi darat berupa truk-truk terbuka dengan kapasitas pengiriman 7,5 ton. Frekuensi pengiriman menjadi hal yang penting perhitungan biaya transportasi dengan daya tampung pabrik yang terbatas. Biaya pengiriman akan disesuaikan dengan jumlah kapasitasnya dimana untuk pengiriman diatas kapasitas akan dihitung dan sisanya dihitung satu kali pengiriman sebagai biaya tambahan. Hasil perhitungan langsung biaya transportasi dari 3 kebun ke 4 pabrik adalah Rp.51.392.000,-Dengan metode Northwest Corner (NWC) diperoleh Rp.48.597.000,- dan solusi optimal modified distribution method (MODI)Rp.48.597.000,-.Output aplikasi POM 5 untuk sain manajemen oleh Taylor Rp.48.597.000,-pada modul linear programming dan transportation. Walaupun hasil optimal sama tetapi jalur distribusi berbeda. Berdasarkan perhitungan langsung dibandingkan optimisasi secara manual maupun dengan output program POM-5. terjadi penurunan biaya transportasi sebesar Rp.2.795.000,- atau 5,44\% dan perusahaan memiliki alternatif jadwal pengiriman yang diinginkan.
\end{abstract}

Kata kunci- program liner,biaya transportasi, NWC, MODI, optimalisasi.

\begin{abstract}
P.T. Agro Muko is an oil palm plantation company and delivers oil palm fruit from plantations in three places, namely Talang Petai Estate, Sei Kiang Estate, and Tanah Rekah Estate. Of the three locations, the oil palm fruit will be shipped to several factories, namely, Muko-Muko, Bunga Tanjung, Bikuk Water, and Air Hitam. Delivery of oil palm fruit using land transportation in the form of open trucks with a delivery capacity of 7.5 tons. The frequency of shipments is an important calculation of transportation costs with limited factory capacity. Shipping costs will be adjusted according to the amount of capacity where shipping above capacity will be calculated and the remainder is calculated as one-time delivery as an additional fee. The result of direct calculation of transportation costs from 3 gardens to 4 factories is Rp.51,392,000,-. With the Northwest Corner (NWC) method, Rp.48,597,000,- is obtained and the optimal modified distribution method (MODI) solution is Rp.48,597,000,-. POM 5 application output for management science by Taylor Rp.48,597,000,- in linear programming and transportation modules. Although the optimal results are the same but the distribution channels are different. Based on direct calculations compared to optimization manually or with the output of the POM-5 program. there was a decrease in transportation costs of Rp.2,795,000,- or 5.44\% and the company had an alternative delivery schedule desired
\end{abstract}

Keywords - linear programming,transportations cost, NWC,MODI, optimization.

\section{Pendahuluan}

$\mathrm{O}$ ptimalisasi, terkait erat pada tujuan-tujuan perusahaan dalam mengelola sumberdaya yang efisien yaitu memaksimumkan produksi, laba dan meminimalkan biayabiaya. Transportasi adalah salah satu aspek atau komponen biaya yang harus diminimalkan. Besar kecilnya biaya yang timbul tergantung pada cara atau metode yang dipilih pada solusi biaya transportasi. Berdasarkan penelitian terdahulu penyelesaian tabel awal menggunakan (NWC), Least Cost dan VAM dioptimalkan dengan metode MODI dan Stepping Stones $[2,5,11,12]$. Artikel ini merupakan pengembangan dari kasus minimalisasi biaya pengiriman buah kelapa sawit PT. Agro Muko menggunakan optimalisasi transportasi metodetabel awal NWC dan optimalisasi dengan metode MODI. Perhtiungan manual menggunakan tabel menurut penulis adalah cara yang lebih mudah dibandingkan dengan cara optimalisasi program linier menggunakan tabel simpleks dengan pengulangan hingga 14 kali (iteration-14). Sebagai pembanding penulis menggunakan perangkat lunak POM 5 pada modulelinear programming dan transportations, Tabel. 13-17 dengan hasil optimal dan menurunkan total biaya perhitungan langsung, Tabel. 9-11.

1. Sampel dan Populasi

\section{Metode Penelitian}

Penelitian ini menggunakan data deret berkala (time series) produksi tahun 2016 sebagai sampel dari populasi sepanjang usia perkebunan sejak berdiri pada tahun sebelum 2016 dan sesudahnya [4].

\section{Sumber Data}

Penulis menggunakan data sekunder berupa data historis tahun 2016 dari penelitian sebelumnya yang dilakukan oleh Mustadin di PT. Agro Muko mempunyai perkebunan di kabupaten Muko-muko yaitu Talang Petai Estate, Sei Kiang Estate, dan Tanah Rekah Estate. Dari ketiga lokasi ini akan melakukan pengiriman buah kelapa sawit ke beberapa pabrik yaitu, Muko-Muko, Bunga Tanjung, Air Bikuk, dan Air Hitam [4]. Distribusi pengiriman dari masing -masing kebun ke pabrik dapat dilihat pada tabel-tabel berikut:

Tabel 1. Distribusi Pengiriman Buah Kelapa Sawit dari Kebun Talang Petai

\begin{tabular}{llcccc}
\multicolumn{1}{c}{ Estate } \\
\hline Dari & Ke & $\begin{array}{c}\text { Kapasitas } \\
\text { (Ton) }\end{array}$ & Frekuensi & $\begin{array}{c}\text { Jumlah } \\
\text { (Ton) }\end{array}$ & $\begin{array}{c}\text { Total } \\
\text { (Ton) }\end{array}$ \\
\hline Talang Petai & Muko- & 7,5 & 10 & 75 & 80 \\
Estate & Muko & 5 & 1 & 5 & \\
Talang Petai & Bunga & 7,5 & 9 & 67,5 & 70 \\
Estate & Tanjung & 2,5 & 1 & 2,5 & \\
Talang Petai & Air & 7,5 & 10 & 75 & 80 \\
Estate & Bikuk & 5 & 1 & 5 & \\
Talang Petai & Air & 7,5 & 2 & 15 & 20 \\
Estate & Hitam & 5 & 1 & 5 & 250 \\
& & Total (Ton) & & & \\
\hline
\end{tabular}


Tabel 2. Distribusi Pengiriman Buah Kelapa Sawit dari Kebun Sei Kiang

\begin{tabular}{|c|c|c|c|c|c|}
\hline \multicolumn{6}{|c|}{ Estate } \\
\hline Dari & $\mathrm{Ke}$ & $\begin{array}{l}\text { Kapasitas } \\
\text { (Ton) }\end{array}$ & Frekuensi & $\begin{array}{l}\text { Jumlah } \\
\text { (Ton) }\end{array}$ & $\begin{array}{r}\text { Total } \\
\text { (Ton) }\end{array}$ \\
\hline Sei Kiang & Muko- & 7,5 & 3 & 15 & 20 \\
\hline Estate & Muko & 5 & 1 & 5 & \\
\hline Sei Kiang & Bunga & 7,5 & 9 & 67,5 & 70 \\
\hline Estate & Tanjung & 2,5 & 1 & 2,5 & \\
\hline Sei Kiang & Air & 7,5 & 5 & 37,5 & 40 \\
\hline Estate & Bikuk & 2,5 & 1 & 2,5 & \\
\hline Sei Kiang & Air & 7,5 & 2 & 15 & 20 \\
\hline Estate & Hitam & 5 & 1 & 5 & \\
\hline & & Total (Ton) & & & 150 \\
\hline
\end{tabular}

Tabel 3. Distribusi Pengiriman Buah Kelapa Sawit dari Kebun Tanah

\begin{tabular}{lllccc}
\multicolumn{1}{c}{ Dari } & Ke & $\begin{array}{c}\text { Kapasitas } \\
\text { (Ton) }\end{array}$ & Frekuensi & $\begin{array}{c}\text { Jumlah } \\
\text { (Ton) }\end{array}$ & $\begin{array}{c}\text { Total } \\
\text { (Ton) }\end{array}$ \\
\hline Tanah Rekah & Muko- & 7,5 & 2 & 15 & 20 \\
Estate & Muko & 5 & 1 & 5 & \\
Tanah Rekah & Bunga & 7,5 & 4 & 30 & 30 \\
Estate & Tanjung & & & & \\
Tanah Rekah & Air & 7,5 & 9 & 67,5 & 70 \\
Estate & Bikuk & 2,5 & 1 & 2,5 & \\
Tanah Rekah & Air & 7,5 & 10 & 75 & 80 \\
Estate & Hitam & 5 & 1 & 5 & \\
& & Total (Ton) & & & 200 \\
\hline
\end{tabular}

Biaya pengiriman dengan kapasitas 7,5 ton sekali kirim. Pengiriman diatas 7,5 ton akan diakumulasi menjadi 1 pengiriman dengan biaya tambahan sesuai tarif yang ditetapkan untuk masing-masing dari kebun ke pabrik (Tabel 4. - Tabel 6.).

Tabel 4.Tarif Pengiriman Buah Kelapa Sawit dari Kebun Talang Petai

\begin{tabular}{cll}
\multicolumn{3}{c}{ Estate } \\
\hline Dari & \multicolumn{1}{c}{ Ke Pabrik } & Tarif/Kirim \\
\hline Kebun Talang Petai Estate & Muko-Muko & Rp. 728.000 \\
Kebun Talang Petai Estate & Bunga Tanjung & Rp. 680.000 \\
Kebun Talang Petai Estate & Air Bikuk & Rp. 823.000 \\
Kebun Talang Petai Estate & Air Hitam & Rp. 919.000 \\
\hline
\end{tabular}

Tabel 5. Tarif Pengiriman Buah Kelapa Sawit dari Kebun Sei Kiang Estate

\begin{tabular}{cll}
\hline Dari & \multicolumn{1}{c}{ Ke Pabrik } & Tarif/Kirim \\
\hline Kebun Sei Kiang Estate & Muko-Muko & Rp. 490.000 \\
Kebun Sei Kiang Estate & Bunga Tanjung & Rp. 442.000 \\
Kebun Sei Kiang Estate & Air Bikuk & Rp. 585.000 \\
Kebun Sei Kiang Estate & Air Hitam & Rp. 680.000 \\
\hline
\end{tabular}

Tabel 6. Tarif Pengiriman Buah Kelapa Sawit dari Kebun Tanah Rekah

\begin{tabular}{lll}
\hline \multicolumn{1}{c}{ Dari } & \multicolumn{1}{c}{ Ke Pabrik } & Tarif/Kirim \\
\hline Kebun Tanah Rekah Estate & Muko-Muko & Rp. 357.000 \\
Kebun Tanah Rekah Estate & Bunga Tanjung & Rp. 309.000 \\
Kebun Tanah Rekah Estate & Air Bikuk & Rp. 452.000 \\
Kebun Tanah Rekah Estate & Air Hitam & Rp. 547.000 \\
\hline
\end{tabular}

3. Waktu dan Tempat

Penelitian ini telah dilakukan oleh Mustadin di perusahaan perkebunan dan pengolahan kelapa sawit PT. Agro Muko Batam Kepulauan Riau [4].

4. Variabel Penelitian

Variabel penelitian menggunakan variabel kuantitatif yaitu jumlah produk buah kelapa sawit (ton) dan tarif pengiriman dari perkebunan ke pabrik (Rp. perkirim).

\section{Kerangka Penelitian}

Secara deskriptif jalur pengiriman dari perkebunan ke pabrik di tujunkan oleh gambar 1 berikut ini:

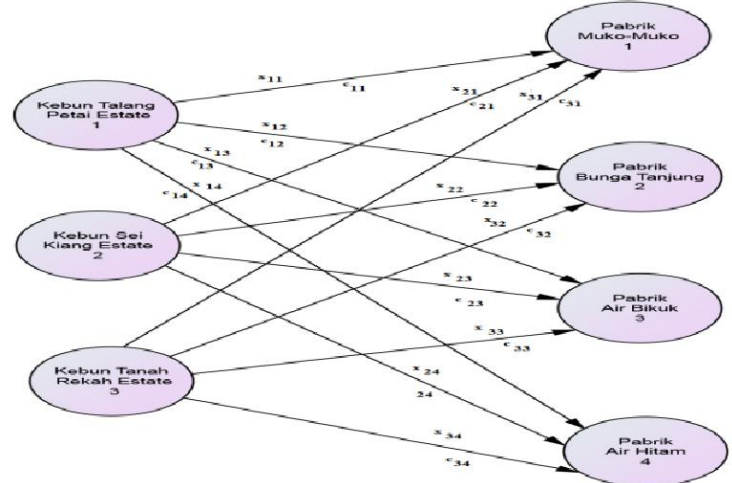

Gambar 1. Jalur Pengriman Buah Kelapa Sawit dari Perkebunan ke Pabrik PT.Agro Muko

6. Teknis Analisis

Bebrapa metode pemecahan permasalahan transportasi yaitu: Program linier (Linear Programming). Metode tabel Awal: Baratlaut atau pojok kiri atas (Northwest Corner $(N W C)$ ), Biaya Sel Minimum (Least Cost Method(LCM)) dan VAM (Vogel Aproximation Method) dan metode tabel Optimal menggunakan metode: Batu Loncatan (Stepping Stones), dan MODI (Modified Distribution Method), $[3,6,7,8,9,10]$.

\section{Tabel Transportasi}

Tabel transportasi terdiri dari sel-sel biaya pengiriman dari sumber ke pabrik, jumlah pasokan dari sumber dan jumlah permintaan pabrik tersimpan di gudang sesuai kapasitas penyimpanan. Matrikulasi masalah transportasi berdasarkan Tabel1.- Tabel 6. dan Gambar 1 maka tabel transportasinya Tabel 7. adalah:

Tabel 7. Tabel Transportasi PT. Agro Muko

\begin{tabular}{|c|c|c|c|c|c|c|c|c|}
\hline $\mathrm{Ke}$ & Miko-Yitiko & & Bunga Taing & & Air Biink & & Ai fitam & Supply \\
\hline Dari & 1 & & 2 & & 3 & & 4 & $\$$ \\
\hline Kebon Talmp Peta Estate & & 80.788.000 & & Ep. 680.000 & & Rp. 8323.000 & Bu. 919.000 & \\
\hline 1 & & & & & & & & 150 \\
\hline Kabon SilKi:no Esate & & R0. 450.000 & & Rp. 442000 & & Rp. 985.100 & $\operatorname{Rn} 6880.000$ & \\
\hline 2 & & & & & & & & [50 \\
\hline Keboun Tanah Retak Estate & & 80.357.000 & & Bp. 309.000 & & Rp. 452.900 & Ro 547.000 & \\
\hline$i$ & & & & & & & & 200 \\
\hline Demand & 120 & & 170 & & 190 & & 120) & 600 \\
\hline
\end{tabular}

Dengan kapasitas pengiriman 7,5 Ton sekali kirim maka batasan supply dan demand dinyatakan dengan frekuensi pengiriman misalnya dari Talang Petai Estate jumlah pasokan 250 Ton setara dengan 250/7,5 = 33,33 dibulatkan menjadi 34 kali pengriman sehingga tabel transportasi berikut Tabel 8:

Tabel 8. Tabel Transportasi Pengiriman Buah Kelapa Sawit P.T. Agro Muko

\begin{tabular}{|c|c|c|c|c|c|}
\hline $\mathrm{Ke}$ & Muko-Muko & Bunga Tanjung & Air Bikuk & Air Hitam & Supply \\
\hline Dari & 1 & 2 & 3 & 4 & S \\
\hline Talang Petai Estate & Rp. 728.000 & Rp. 680.000 & Rp. 823.000 & Rp. 919.000 & \\
\hline 1 & & & & & 34 \\
\hline Sei Kiang Estate & Rp. 490.000 & Rp. 442.000 & $\operatorname{Rp} .585 .000$ & Rp. 680.000 & \\
\hline 2 & & & & & 20 \\
\hline Tanah Rekah Estate & Rp. 357.000 & Rp. 309.000 & Rp. 452.000 & Rp. 547.000 & \\
\hline 3 & & & & & 27 \\
\hline Demand & 16 & 23 & 26 & 16 & 81 \\
\hline
\end{tabular}


Penulis menggunakan pemecahan masalah transportasi dengan metode tabel awal NWC dan optimisasi metode MODI serta output program apliaksi POM-5 pada modul Linear Programming dan Transportations.

\section{Program Linier (Linear Programming)}

Program liner memiliki 2 kelompok persamaan dan pertidaksamaan yaitu persamaan fungsi tujuan (objective) dalam kasus ini adalah mencari total biaya transportasi minimum dan kelompok pertidak samaan fungsi kendala (constraint).Tiga pasokan dari kebun pada kota Talang Petai Estate, Sei Kiang Estate, dan Tanah Rekah Estate dengan tujuan ke empat pabrik yang ada di Muko Muko, Bunga Tanjung, Air Bikuk, dan Air Hitam menghasilkan 7 pertidaksamaan sebanyak 3 pertidaksamaan pada sisi pasokan (supply) dan 4 pertidaksamaan pada sisi permintaan (demand). Tahapan penyelesaian program linier dengan membuat definisi variabel, persamaan dan pertidaksamaan dan transformasi ke solusi tabel simpleks.Definisi untuk masing-masing variabel pada kasus ini secara umum berdasarkan informasi sejumlah pasokan dan permintaan dan biaya variabel pengiriman adalah sebagai berikut $[3,6,7,8,9,10]$ :

$\mathrm{x}_{\mathrm{ij}}=$ jumlah buah kelapa sawit yang dikirim dari kebun $\mathrm{i}$ ke pabrik $\mathrm{j}, \quad(\mathrm{i}, \mathrm{j}=$ $1,2,3, \ldots)$

$\mathrm{c}_{\mathrm{ij}}=$ biaya pengiriman buah kelapa sawit dari kebun $\mathrm{i}$ ke pabrik $\mathrm{j}, \quad(\mathrm{i}, \mathrm{j}=$ $1,2,3, \ldots)$

$\min =\sum_{\substack{i=1 \\ \text { terbatas pada: } \\ j=m}}^{i=m} \sum_{j=1}^{j=n} c i j x i j$
$\sum_{j=1} x i j \leq S i(i=1,2,3, \ldots m) \quad$ (Batasan Pasokan)

$\sum_{i=1}^{i=n} x i j \geq D j(j=1,2,3, \ldots n) \quad$ (Batasan Permintaan)

$x i j \geq 0, \quad(i=1,2,3, \ldots, m) \quad$ dan $\quad(j=1,2,3, \ldots n)$

Untuk transportasi berkeseimbangan (balance transportation problems) jumlah pasokan dan permintaan buah kelapa sawit sama dirumuskan sebagai berikut:

$\sum_{i=1}^{i=m} S i=\sum_{j=1}^{j=n} D j$

\section{Algoritma Simpleks Masalah Minimum}

Ada 2 cara menurut Winstone yaitu (1) dengan mengalikan negatif pada fungsi tujuan lalu selesaikan dengan algoritma masalah maksimum; (2). Pemecahan langsung dengan merubah langkah 3 (f) pada baris $\mathrm{Cj}-\mathrm{Z}$ untuk optimal dengan nilai nol atau positif, [10].

a. Ubah Progran Linier ke bentuk standard

Bentuk Standar dimana pertidaksamaan diubah menjadi persamaan dengan menambahkan variabel slack pada fungsi tujuan dan kendala . Nilai fungsi tujuan setelah ditambah variabel slack adalah nol

b. Ubah ke Tabel dari bentuk standar

c. Tentukan Optimalisasi berdasarkan Tabel sebagai berikut:

1) Pilih nilai positif terbesar dari fungsi tujuan sebagai kolom kunci.

2) Tentukan baris kunci dengan menghitung rasio kuantitas dengan elemen kolom kunci pilih rasio terkecil.

3) Tentukan Elemen pivot yaitu perpotongan Kolom Kunci dengan Baris kunci.

4) Hitung baris baru entering variabel dengan membagi baris kunci dengan elemet pivot.

5) Hitung Baris Baru Variabel lainnya menggunakan ERO atau Elimanasi Gauss -Jordan secara baris

6) Periksa baris $\mathrm{Cj}-\mathrm{Z}$ pada Tabel hasil iterasi 2 apakah masih ada nilai nol atau positif

d. Jika belum optimal lanjutkan ke Iterasi ke3 berdasarkan tabel Iterasi 2 dengan mengulangi langkah

10. Metode Tabel Transportasi Solusi awal tabel transportasi ada 3 yaitu NWC, Biaya Sel Minimum dan VAM. Pada artikel ini penulis menggunakan solusi awal NWC dengan alasan algoritma mudah lebih mudah disbanding solusi tabel awal metode Least Cost dan VAM.

\section{Metode Tabel Awal NWC}

Algoritma NWC Algoritma penyelesaian total biaya minimal [3,6,7,8.9.10] menggunakan matriks pada perhitungan berulang (itersi) untuk solusi optimal simpleks lebih sulit fi bandingkan dengan solusi tabel transportasi metode Northwest Corner (NWC) menurut Charnes dan Cooper, kemudian dikembangkan oleh Danzig [4] sebagai berikut:

a. Alokasikan sebanyak-banyaknya jumlah pasokan barang ke pojok kiri atas sesuai permintaan.

b. Apakah pengiriman dari sumber ke tujuan sudah dipenuhi jika "ya" tutup jalur tersebut dan jika "tidak" ulangi langkah ke 1 .

c. Jika semua permintaan sudah dipenuhi oleh pasokan buat jadwal pemgiriman,

d. Hitung total biaya minimum sesuai jadwal pengiriman.

\section{Metode Tabel Optimal MODI}

Metode ini memperhitungkan Opportunity cost $\left(\mathrm{O}_{\mathrm{ij}}\right)$ dengan 2 tahap yaitu, 1).Evaluasi sel isi untuk menentukan angka kunci baris dan kolom. 2). Evaluasi sel kosong untuk memperolehOpportunity cost $\left(\mathrm{O}_{\mathrm{ij}}\right)$ menggunakan angka kunci dari langkah 1). Jika hasil evaluasi sel kosong memiliki opportunity cost nol atau negative atau tabel dinyatakan optimal jika dan hanya jika $\mathrm{U}_{\mathrm{i}}+\mathrm{V}_{\mathrm{j}}-\mathrm{C}_{\mathrm{ij}} \leq 0$. Persamaan Opportunity cost $\left(\mathrm{O}_{\mathrm{ij}}\right)$ adalah:

$\mathrm{O}_{\mathrm{ij}}=\left(\mathrm{U}_{\mathrm{i}}+\mathrm{V}_{\mathrm{j}}\right)-\mathrm{C}_{\mathrm{ij}}$ 
dimana, $\mathrm{U}_{\mathrm{i}}=$ Angka kunci pada setiap baris $\mathrm{I}, \mathrm{V}_{\mathrm{j}}=$ Angka kunci pada setiap kolom $\mathrm{j}$

$\mathrm{C}_{\mathrm{ij}}=$ Biaya distribusi yang nyata pada sel $\mathrm{ij}$

Algoritma Metode MODI sebagai berikut:

a. Menentukan tabel awal yang fisibel dengan menggunakan metode NWCatau metode ongkos terkecil atau VAM.

b. Menambahkan variabel $\mathrm{Ui}$ dan $\mathrm{Vj}$ pada setiap baris dan kolom.

c. Mencari nilai Rimaupun Kjuntuk setiap sel basis dengan menggunakan rumus $: \mathrm{Ui}+\mathrm{Vj}=$ Cijdengan memisahkan salah satu nilai Uiatau Vjsama dengan nol.

d. Menghitung semua nilai sel bukan basis dengan menggunakan rumus $\mathrm{Cij}-\mathrm{Ui}-\mathrm{Vj}$.

e. Menentukan sel yang akan masuk basis dengan memilih nilai sel bukan basis yang memiliki nilai negatif terbesar. Kemudian membuat closed path untuk menentukan sel yang akan keluar dengan memilihjumlah unit terkecil dari sel yang bertanda negatif.

f. Tabel optimum tercapai apabila sel bukan basis semuanya memiliki nilai $=0$.

g. Jika tabel belum optimum, kembali ke langkah b sehingga ditemukan tabel optimum.

\section{HASIL DAN PEMBahasan}

\section{Perhtungan Biaya Total Secara Langsung}

Perhitungan biaya pengiriman buah kelapa sawit dan total biaya berdasarkan tariff sekal kirim dari kebun ke pabrik (Tabel 1. -Tabel6.) disajikan pada (Tabel 9) untuk biaya pengriman Kebun Talang Petai Estate, Dari Kebun Sei Kiang Estate (Tabel 10) dan dari Kebun Tanah Rekah Estate (Tabel 11.) masing-masing sebagai berikut.

Tabel 9. Distribusi Biaya Pengiriman Buah Kelapa Sawit dari Kebun

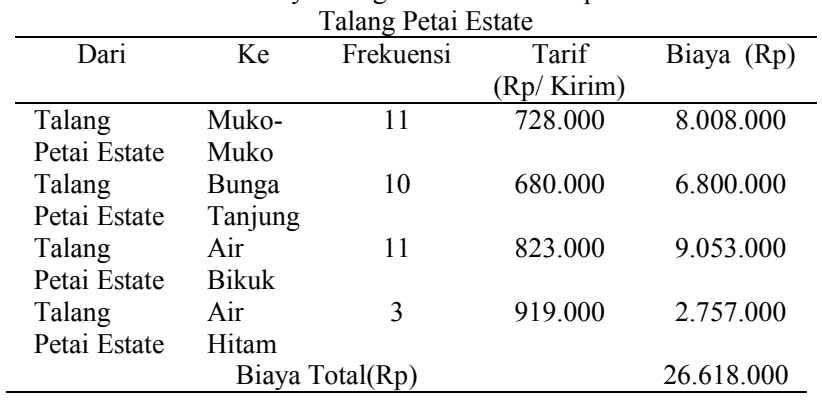

Tabel 10. Distribusi Biaya Pengiriman Buah Lelapa Sawit dari Kebun Sei

\begin{tabular}{|c|c|c|c|c|}
\hline \multicolumn{5}{|c|}{ Kiang Estate } \\
\hline Dari & $\mathrm{Ke}$ & Frekuensi & $\begin{array}{c}\text { Tarif } \\
\text { (Rp/Kirim) }\end{array}$ & Biaya (Rp) \\
\hline $\begin{array}{l}\text { Sei Kiang } \\
\text { Estate }\end{array}$ & $\begin{array}{l}\text { Muko- } \\
\text { Muko }\end{array}$ & 4 & 490.000 & 1.960 .000 \\
\hline $\begin{array}{l}\text { Sei Kiang } \\
\text { Estate }\end{array}$ & $\begin{array}{l}\text { Bunga } \\
\text { Tanjung }\end{array}$ & 10 & 442.000 & 4.420 .000 \\
\hline $\begin{array}{l}\text { Sei Kiang } \\
\text { Estate }\end{array}$ & $\begin{array}{l}\text { Air } \\
\text { Bikuk }\end{array}$ & 6 & 585.000 & 3.510 .000 \\
\hline $\begin{array}{l}\text { Sei Kiang } \\
\text { Estate }\end{array}$ & $\begin{array}{l}\text { Air } \\
\text { Hitam }\end{array}$ & 3 & 680.000 & 2.040 .000 \\
\hline & Biays & Total (Rp) & & 11.930 .000 \\
\hline
\end{tabular}

Tabel 11. Distribusi Biaya pengiriman buah kelapa sawit dari Kebun Tanah Rekah Estate

\begin{tabular}{|c|c|c|c|c|}
\hline Dari & $\mathrm{Ke}$ & Frekuensi & $\begin{array}{c}\text { Tarif } \\
(\text { Rp/Kirim })\end{array}$ & Biaya (Rp) \\
\hline $\begin{array}{l}\text { Tanah Rekah } \\
\text { Estate }\end{array}$ & $\begin{array}{l}\text { Muko- } \\
\text { Muko }\end{array}$ & 3 & 357.000 & 1.071 .000 \\
\hline Tanah Rekah & Bunga & 4 & 309.000 & 1.236 .000 \\
\hline Estate & Tanjung & & & \\
\hline $\begin{array}{l}\text { Tanah Rekah } \\
\text { Estate }\end{array}$ & $\begin{array}{l}\text { Air } \\
\text { Bikuk }\end{array}$ & 10 & 452.000 & 4.520 .000 \\
\hline Tanah Rekah & Air & 11 & 547.000 & 6.017 .000 \\
\hline Estate & $\begin{array}{l}\text { Hitam } \\
\text { Biaya }\end{array}$ & tal (Rp) & & 12.844 .000 \\
\hline
\end{tabular}

Total biaya transportasi sebelum dioptimalisasi berdasrakan Tabel 9-11adalah Rp. 51.392.000,-

\section{Program Linier}

Program Linier menggunakan definisi variabel persamaan (1)-(5) diubah menjadi persamaan standar pada tujuan $\mathrm{Z}$ dikalikan negatif dengan menambahkan variabel slack (S) dan artificial (A) berkoefisien nol (7). Pada persamaan (8)(10) kendala supply tambahkan slack positif. Persamaan (11)-(15)untuk kendala demand tambahkan slack negative dan artificial sehinggadengan penyederhanaan per 1000 unit maka LP adalah:

$\operatorname{Min}(-Z)=728 X_{1}+680 X_{2}+823 X_{3}+919 X_{4}+490 X_{5}+442 X_{6}+585 X_{7}+$ $680 \mathrm{X}_{8}+357 \mathrm{X}_{9}+309 \mathrm{X}_{10}+452 \mathrm{X}_{11}+547 \mathrm{X}_{12}+0 \mathrm{~S}_{1}+0 \mathrm{~S}_{2}+0 \mathrm{~S}_{3}+0 \mathrm{~A}_{4}+0 \mathrm{~S}_{4}+0 \mathrm{~A}_{5}+0 \mathrm{~S}_{5}+$ $0 \mathrm{~A}_{6}+0 \mathrm{~S}_{6}+0 \mathrm{~A}_{7}+0 \mathrm{~S}_{7}$

terbatas pada

$\mathrm{X}_{1}+\mathrm{X}_{2}+\mathrm{X}_{3}+\mathrm{X}_{4}+\mathrm{S}_{1}=34$ (Batasan Pasokan Talang Petai Estate)

$\mathrm{X}_{5}+\mathrm{X}_{6}+\mathrm{X}_{7}+\mathrm{X}_{8}+\mathrm{S}_{2}=20$ (Batasan Pasokan Sei Kiang Estate)

$\mathrm{X}_{9}+\mathrm{X}_{10}+\mathrm{X}_{11}+\mathrm{X}_{12}+\mathrm{S}_{3}=27$ (Batasan Pasokan Tanah Rekah Estate)

$\mathrm{X}_{1}+\mathrm{X}_{5}+\mathrm{X}_{9}+\mathrm{A}_{4}-\mathrm{S}_{4}=16$ (Batasan Permintaan Muko-muko)

$\mathrm{X}_{2}+\mathrm{X}_{6}+\mathrm{X}_{10}+\mathrm{A}_{5}-\mathrm{S}_{5}=23$ (Batasan Permintaan Bunga Tanjung)

$\mathrm{X}_{3}+\mathrm{X}_{7}+\mathrm{X}_{11}+\mathrm{A}_{6}-\mathrm{S}_{6}=26$ (Batasan Permintaan Air Bikuk)

$\mathrm{X}_{4}+\mathrm{X}_{8}+\mathrm{X}_{12}+\mathrm{A}_{7}-\mathrm{S}_{7}=16$ (Batasan Permintaan Air Hitam)

$\mathrm{X}_{1}, \mathrm{X}_{2}, \mathrm{X}_{3}, \mathrm{X}_{4}, \mathrm{X}_{5}, \mathrm{X}_{6}, \mathrm{X}_{7}, \mathrm{X}_{8}, \mathrm{X}_{9}, \mathrm{X}_{10}, \mathrm{X}_{11}, \mathrm{X}_{12} \geq 0$ (Non Negatif),

dimana:

$\mathrm{X}_{1}=$ Talang Petai Estate - Muko-Muko

$\mathrm{X}_{2}=$ Talang Petai Estate - Bunga Tanjung

$\mathrm{X}_{3}=$ Talang Petai Estate- Air Bikuk

$\mathrm{X}_{4}=$ Talang Petai Estate- Air Hitam

$\mathrm{X}_{5}=$ Sei Kiang Estate- Muko-Muko

$\mathrm{X}_{6}=$ Sei Kiang Estate- Bunga Tanjung

$\mathrm{X}_{7}=$ Sei Kiang Estate- Air Bikuk

$\mathrm{X}_{8}=$ Sei Kiang Estate- Air Hitam

$\mathrm{X}_{9}=$ Tanah Rekah Estate- Muko-Muko

$\mathrm{X}_{10}=$ Tanah Rekah Estate- Bunga Tanjung

$\mathrm{X}_{11}=$ Tanah Rekah Estate- Air Bikuk

$\mathrm{X}_{12}=$ Tanah Rekah Estate- Air Hitam

Langkah selanjutnya adalah dengan trasformasi bentuk standar ke tabel 12 simpleks berikut:

Perhitungan biaya total optimal dan jalur pengiriman Tabel 14 program linier menggunakan Tabel Simpleks Tabel 13 adalah sebagai berikut:

\section{Metode Tabel Transportasi}

Prosedur perhitungan dimulai dengan merumuskan permasalahan kedalan program liner kemudian transformasi bentuk program liner ke tabel transportasi untuk pemecahan menggunakan metode NWC dan MODI. 
Tabel 12. Simpleks- Optimal-Iterasi 14

\begin{tabular}{|c|c|c|c|c|c|c|c|c|c|c|c|c|c|c|c|c|c|c|c|c|c|c|}
\hline $\mathrm{Cj}$ & $\begin{array}{c}\text { Basic } \\
\text { Variables } \\
\end{array}$ & Quantity & $\begin{array}{c}728 . \\
X_{1}\end{array}$ & $\begin{array}{c}680 . \\
X_{2}\end{array}$ & $\begin{array}{c}823 . \\
X_{3}\end{array}$ & $\begin{array}{c}919 . \\
\mathrm{X}_{4}\end{array}$ & $\begin{array}{c}490 . \\
X_{5}\end{array}$ & $\begin{array}{c}442 . \\
X_{6}\end{array}$ & 9 & $\begin{array}{r}680 . \\
\mathrm{X}_{8}\end{array}$ & $\begin{array}{c}357 . \\
\mathrm{X}_{9}\end{array}$ & $\begin{array}{c}309 . \\
X_{10}\end{array}$ & $\begin{array}{r}452 . \\
X_{11}\end{array}$ & $\begin{array}{l}547 . \\
X_{12} \\
\end{array}$ & $0 \mathrm{~A}_{4}$ & $0 \mathrm{~S}_{4}$ & $0 \mathrm{~A}_{5}$ & $0 \mathrm{~S}_{5}$ & $0 \mathrm{~A}_{6}$ & $0 \mathrm{~S}_{6}$ & $0 \mathrm{~A}_{7}$ & $0 \mathrm{~S}_{7}$ \\
\hline 309 & $\mathrm{X}_{10}$ & 19 & 0 & 1 & 0 & 1 & -1 & 0 & -1 & 0 & 0 & 1 & 0 & 1 & 0 & 0 & 1 & 0 & 0 & 0 & 0 & 0 \\
\hline 442 & $\mathrm{X}_{6}$ & 4 & 0 & 0 & 0 & -1 & 1 & 1 & 1 & 0 & 0 & 0 & 0 & -1 & 0 & 0 & 0 & 0 & 0 & 0 & 0 & 0 \\
\hline 680 & $\mathrm{X}_{8}$ & 16 & 0 & 0 & 0 & 1 & 0 & 0 & 0 & 1 & 0 & 0 & 0 & 1 & 0 & 0 & 0 & 0 & 0 & 0 & 0 & 0 \\
\hline 823 & $\mathrm{X}_{3}$ & 26 & 0 & 0 & 1 & 0 & 0 & 0 & 1 & 0 & 0 & 0 & 1 & 0 & 0 & 0 & 0 & 0 & 0 & 0 & 0 & 0 \\
\hline 728 & $X_{1}$ & 8 & 1 & 1 & 0 & 1 & 0 & 0 & -1 & 0 & 0 & 0 & -1 & 0 & 1 & -1 & 1 & -1 & 0 & 0 & 0 & 0 \\
\hline 357 & $\mathrm{X}_{9}$ & 8 & 0 & -1 & 0 & -1 & 1 & 0 & 1 & 0 & 1 & 0 & 1 & 0 & 0 & 0 & -1 & 0 & 1 & -1 & 0 & 0 \\
\hline 0 & $\mathrm{~S}_{1}$ & 0 & 0 & 0 & 0 & 0 & 0 & 0 & 0 & 0 & 0 & 0 & 0 & 0 & -1 & 1 & -1 & 0 & 0 & 0 & 1 & -1 \\
\hline & $\mathrm{Zj}$ & 48,597 & 728 & 680 & 823 & 920 & 490 & 442 & 585 & 680 & 357 & 309 & 452 & 547 & -728 & 728 & -680 & 1 & 1 & 1 & 1 & 1 \\
\hline & $\mathrm{Cj}-\mathrm{Zj}$ & & 0 & 0 & 0 & $-1,000$ & 0 & 0 & 0 & 0 & 0 & 0 & 0 & 0 & 728 & -728 & 680 & -1 & 0 & -1 & 0 & -1 \\
\hline
\end{tabular}

Tabel 13. Perhitungan Biaya Total dan Jalur Pengiriman Optimal

\begin{tabular}{|c|c|c|c|}
\hline Jalur & Frekuensi & Biaya per kirim & Jumlah \\
\hline $\begin{array}{l}\text { Tanah Rekah Estate - } \\
\text { Bunga Tanjung }\end{array}$ & 19 & Rp. 309.000 & Rp. 5.871.000 \\
\hline $\begin{array}{l}\text { Sei Kiang Estate - } \\
\text { Bunga Tanjung }\end{array}$ & 4 & Rp. 442.000 & Rp. 1.768 .000 \\
\hline $\begin{array}{l}\text { Sei Kiang Estate - } \\
\text { Air Hitam }\end{array}$ & 16 & Rp. 680.000 & Rp. 10.880 .000 \\
\hline $\begin{array}{l}\text { Sei Kiang Estate - } \\
\text { Muko-Muko }\end{array}$ & 26 & Rp. 823.000 & Rp.21.398.000 \\
\hline $\begin{array}{l}\text { Talang Petai Estate - } \\
\text { Muko-Muko }\end{array}$ & 8 & Rp. 728.000 & Rp. 5.824 .000 \\
\hline \multirow[t]{2}{*}{$\begin{array}{l}\text { Tanah Rekah Estate - } \\
\text { Muko-Muko }\end{array}$} & 8 & Rp. 357.000 & Rp. 2.856 .000 \\
\hline & & Biaya Total & Rp.48.597.000 \\
\hline
\end{tabular}

\section{Program Linier}

Min $Z=728.000 \mathrm{x}_{11}+680.000 \mathrm{x}_{12}+823.000 \mathrm{x}_{13}+919.000 \mathrm{x}_{14}+490.000$ $\mathrm{x}_{21}+442.000 \mathrm{x}_{22}+585.000 \mathrm{x}_{23}+680.000 \mathrm{x}_{24}+357.000 \mathrm{x}_{31}+309.000 \mathrm{x}_{32}+$ $452.000 \mathrm{x}_{33}+547.000 \mathrm{x}_{34}$

\section{terbatas pada}

$\mathrm{x}_{11}+\mathrm{x}_{12}+\mathrm{x}_{13}+\mathrm{x}_{14} \geq 34$ (Batasan Pasokan Talang Petai Estate)

$\mathrm{x}_{21}+\mathrm{x}_{22}+\mathrm{x}_{23}+\mathrm{x}_{24} \geq 20$ (Batasan Pasokan Sei Kiang Estate)

$\mathrm{x}_{31}+\mathrm{x}_{32}+\mathrm{x}_{33}+\mathrm{x}_{34} \geq 27$ (Batasan Pasokan Tanah Rekah Estate)

$\mathrm{x}_{11}+\mathrm{x}_{21}+\mathrm{x}_{31} \geq 16$ (Batasan Permintaan Muko-muko)

$\mathrm{x}_{12}+\mathrm{x}_{22}+\mathrm{x}_{32} \geq 23$ (Batasan Permintaan Bunga Tanjung)

$\mathrm{x}_{13}+\mathrm{x}_{23}+\mathrm{x}_{33} \geq 26$ (Batasan Permintaan Air Bikuk)

$\mathrm{x}_{14}+\mathrm{x}_{24}+\mathrm{x}_{34} \geq 16$ (Batasan Permintaan Air Hitam)

$\mathrm{x}_{11}, \mathrm{x}_{12}, \mathrm{x}_{13}, \mathrm{x}_{14}, \mathrm{x}_{21}, \mathrm{x}_{22}, \mathrm{x}_{23}, \mathrm{x}_{24}, \mathrm{x}_{31}, \mathrm{x}_{32}, \mathrm{x}_{33}, \mathrm{x}_{34} \geq 0$ (Non Negatif)

\section{Dimana:}

$\mathrm{x}_{11}=$ Talang Petai Estate - Muko-Muko

$\mathrm{x}_{12}=$ Talang Petai Estate - Bunga Tanjung

$\mathrm{x}_{13}=$ Talang Petai Estate - Air Bikuk

$\mathrm{x}_{14}=$ Talang Petai Estate - Air Hitam

$\mathrm{x}_{21}=$ Sei Kiang Estate - Muko-Muko

$\mathrm{x}_{22}=$ Sei Kiang Estate - Bunga Tanjung

$\mathrm{x}_{23}=$ Sei Kiang Estate - Air Bikuk

$\mathrm{x}_{24}=$ Sei Kiang Estate - Air Hitam

$\mathrm{x}_{31}=$ Tanah Rekah Estate - Bunga Tanjung

$\mathrm{x}_{32}=$ Tanah Rekah Estate- Air Bikuk

$\mathrm{x}_{23}=$ Tanah Rekah Estate- Air Hitam

\section{Metode Tabel Awal NWC}

Solusi tabel transportasi menggunakan algoritma NWC (Tabel 14.) dan jadwal pengirimannya Tabel 16. masingmasing diperoleh sebagai berikut:

Tabel 14. Solusi Transportasi Metode NWC

\begin{tabular}{|c|c|c|c|c|c|c|c|c|}
\hline $\mathrm{Ke}$ & Muk & Muko & Bunge & Tanjung & & Bikuk & Air Hitam & Supply \\
\hline Dari & & 1 & & 2 & & 3 & 4 & $\mathrm{~s}$ \\
\hline Talang Petai Estate & & Rp. 728.000 & & Rp. 680.000 & & Rp. 823.000 & Rp. 919.000 & \\
\hline 1 & 16 & & 18 & & & & & 34 \\
\hline Sei Kiang Estate & & Rp. 490.000 & & Rp. 442.000 & & Rp. 585.000 & Rp. 680.000 & \\
\hline 2 & & & 5 & & 15 & & & 20 \\
\hline Tanah Rekah Estate & & Rp. 357.000 & & Rp. 309.000 & & Rp. 452.000 & Rp. 547.000 & \\
\hline 3 & & & & & 11 & & 16 & 27 \\
\hline Demand & 16 & & 23 & & 26 & & 16 & 81 \\
\hline
\end{tabular}

Tabel 15. Perhitungan Biaya Total dan Jalur Pengiriman Metode NWC

\begin{tabular}{lccc}
\hline \multicolumn{1}{c}{ Jalur } & Frekuensi & $\begin{array}{c}\text { Biaya per } \\
\text { kirim }\end{array}$ & Jumlah \\
\hline $\begin{array}{l}\text { Talang Petai Estate- } \\
\text { Muko-Muko }\end{array}$ & 16 & Rp. 728.000 & Rp. 11.648 .000 \\
$\begin{array}{l}\text { Talang Petai Estate- } \\
\text { Bunga Tanjung }\end{array}$ & 18 & Rp. 680.000 & Rp. 12.240 .000 \\
$\begin{array}{l}\text { Sei Kiang Estate- } \\
\text { Bunga Tanjung } \\
\text { Sei Kiang Estate- }\end{array}$ & 6 & Rp. 442.000 & Rp. 2.210 .000 \\
$\begin{array}{l}\text { Air Bikuk } \\
\text { Tanah Rekah -Estate } \\
\text { Air Bikuk } \\
\text { Tanah Rekah Estate- }\end{array}$ & 11 & Rp. 585.000 & Rp. 8.775 .000 \\
Air Hitam & 16 & Rp. 452.000 & Rp. 4.972 .000 \\
\hline
\end{tabular}

\section{Metode Tabel Optimal MODI}

Solusi tabel NWC belum optimal artinya biaya total minimal masih dapat diturunkan. Optimalisasi menggunakan tabel MODI menurut Siswanto dengan mengevaluasi sel isi untuk dialokasikan ke tabel kosong menggunakan algoritma berikut [6]:

Menentukan angka kunci pada $U_{i}$ dan $V_{j}$ sebarang menurut baris atau kolom untuk menentukan angka kunci yang lain. Uji sel kosong menurut tabel NWC berikut:

Tabel 16. Solusi Transportasi Metode NWC

\begin{tabular}{|c|c|c|c|c|c|c|c|c|}
\hline $\mathrm{Ke}$ & Muks & - Muko & Bung & Tanjung & & Bikuk & Air Hitam & Supply \\
\hline Dari & & 1 & & 2 & & 3 & 4 & $\mathrm{~s}$ \\
\hline Talang Petai Estate & & Rp. 728.000 & & Rp. 680.000 & & Rp. 823.000 & Kp. 919.000 & \\
\hline 1 & 16 & & 18 & & & & & 34 \\
\hline Sei Kiang Estate & & Rp. 490.000 & & Rp. 442.000 & & Rp. 585.000 & Rp. 680.000 & \\
\hline 2 & & & 5 & & 15 & & & 20 \\
\hline Tanah Rekah Estate & & Rp. 357.000 & & Rp. 309.000 & & Rp. 452.000 & Rp. 547.000 & \\
\hline 3 & & & & & 11 & & 16 & 27 \\
\hline Demand & 16 & & 23 & & 26 & & 16 & 81 \\
\hline
\end{tabular}

\section{1). Perhitungan angka kunci pada Sel Isi:}

Sel isi $\mathrm{x}_{11}$ dengan, $\mathrm{i}=1$ dan $\mathrm{j}=1$ untuk seluruh sel isi $\mathrm{O}_{\mathrm{ij}}$ $=0$

$\mathrm{O}_{11}=\mathrm{U}_{1}+\mathrm{V}_{1}-\mathrm{C}_{11 ; 0}=\mathrm{U}_{1}+\mathrm{V}_{1}-\mathrm{C}_{11}$ maka $\mathrm{U}_{1}+\mathrm{V}_{1}=\mathrm{C}_{11}$

$\mathrm{U}_{1}$ diberikana angka sembarang misalnya $\mathrm{U}_{1}=0$ (boleh angka lain) maka $\mathrm{V}_{1}=\mathrm{C}_{11}=728.000$

Sel isi $\mathrm{x}_{12}$ dengan $\mathrm{i}=1$ dan $\mathrm{j}=2$ untuk sel isi $\mathrm{O}_{12}=0$ $\mathrm{O}_{12}=\mathrm{U}_{1}+\mathrm{V}_{2}-\mathrm{C}_{12} ; 0=\mathrm{U}_{1}+\mathrm{V}_{2}-\mathrm{C}_{12}$ maka $\mathrm{U}_{1}+\mathrm{V}_{2}=$ $\mathrm{C}_{12}$ untuk $\mathrm{U}_{1}=0$ maka $\mathrm{V}_{2}=\mathrm{C}_{12}=680.000$

Sel isi $\mathrm{x}_{22}$ dengan $\mathrm{i}=2$ dan $\mathrm{j}=2$ untuk sel isi $\mathrm{O}_{22}=0$ $\mathrm{O}_{22}=\mathrm{U}_{2}+\mathrm{V}_{2}-\mathrm{C}_{22} ; 0=\mathrm{U}_{2}+680.000-442.000$ maka $\mathrm{U}_{2}=$ $442.000-680.000=-238.000$

Sel isi $\mathrm{x}_{23}$ dengan $\mathrm{i}=2$ dan $\mathrm{j}=3$ untuk sel isi $\mathrm{O}_{23}=0$

$\mathrm{O}_{23}=\mathrm{U}_{2}+\mathrm{V}_{3}-\mathrm{C}_{23} ; 0=-238.000+\mathrm{V}_{3}-585.000$ maka $\mathrm{V}_{3}=$ $585.000+238.000=823.000$

Sel isi $\mathrm{x}_{33}$ dengan $\mathrm{i}=3$ dan $\mathrm{j}=3$ untuk sel isi $\mathrm{O}_{33}=0$

$\mathrm{O}_{33}=\mathrm{U}_{3}+\mathrm{V}_{3}-\mathrm{C}_{33} ; 0=\mathrm{U}_{3}+823.000-452.000$ maka $\mathrm{U}_{3}=$ $452.000-823.000=-371.000$ 
Sel isi $\mathrm{x}_{34}$ dengan $\mathrm{i}=3$ dan $\mathrm{j}=4$ untuk sel isi $\mathrm{O}_{34}=0$

$\mathrm{O}_{34}=\mathrm{U}_{3}+\mathrm{V}_{4}-\mathrm{C}_{34} ; 0=-371.000+\mathrm{V}_{4}-547.000$ maka $\mathrm{V}_{4}=$ $371.000+547.000=918.000$

\section{2). Perhitungan Opportunity Cost Sel Kosong}

Sel kosong $\mathrm{x}_{13}$ maka $\mathrm{O}_{13}=\mathrm{U}_{1}+\mathrm{V}_{3}-\mathrm{C}_{13} ; \mathrm{O}_{13}=0+$ $823.000-823.000=0$

Sel kosong $\mathrm{x}_{14}$ maka $\mathrm{O}_{14}=\mathrm{U}_{1}+\mathrm{V}_{4}-\mathrm{C}_{14} ; \mathrm{O}_{14}=0+$ $918.000-919.000=-1.000$

Sel kosong $\mathrm{x}_{21}$ maka $\mathrm{O}_{21}=\mathrm{U}_{2}+\mathrm{V}_{1}-\mathrm{C}_{21} ; \mathrm{O}_{21}=-238.000$ $+728.000-490.000=0$

Sel kosong $\mathrm{x}_{24}$ maka $\mathrm{O}_{24}=\mathrm{U}_{2}+\mathrm{V}_{4}-\mathrm{C}_{24} \quad ; \mathrm{O}_{24}=-238.000$ $+918.000-680.000=0$

Sel kosong $\mathrm{x}_{31}$ maka $\mathrm{O}_{31}=\mathrm{U}_{3}+\mathrm{V}_{1}-\mathrm{C}_{31} ; \mathrm{O}_{21}=-371.000$ $+728.000-357.000=0$

Sel kosong $\mathrm{x}_{32}$ maka $\mathrm{O}_{32}=\mathrm{U}_{3}+\mathrm{V}_{2}-\mathrm{C}_{32} \quad ; \mathrm{O}_{24}=-371.000$ $+680.000-309.000=0$

Opportunity Cost $\leq 0$ artinya solusi sudah optimal. Evaluasi sel pada metode NWC dengan MODI pada kasus ini ternyata optimal Tabel 16.

Tabel 16. Perhitungan Biaya Total dan Jalur Pengiriman Metode NWC-

\begin{tabular}{|c|c|c|c|}
\hline Jalur & Frekuensi & $\begin{array}{l}\text { Biaya per } \\
\text { kirim }\end{array}$ & Jumlah \\
\hline $\begin{array}{c}\text { Talang Petai Estate- } \\
\text { Muko-Muko }\end{array}$ & 16 & Rp. 728.000 & Rp. 11.648.000 \\
\hline $\begin{array}{c}\text { Talang Petai Estate- } \\
\text { Bunga Tanjung }\end{array}$ & 18 & Rp. 680.000 & Rp. 12.240 .000 \\
\hline $\begin{array}{l}\text { Sei Kiang Estate- } \\
\text { Bunga Tanjung }\end{array}$ & 6 & Rp. 442.000 & Rp. $\quad 2.210 .000$ \\
\hline $\begin{array}{c}\text { Sei Kiang Estate- } \\
\text { Air Bikuk }\end{array}$ & 15 & Rp. 585.000 & Rp. 8.775 .000 \\
\hline $\begin{array}{c}\text { Tanah Rekah -Estate } \\
\text { Air Bikuk }\end{array}$ & 11 & Rp. 452.000 & Rp. 4.972 .000 \\
\hline $\begin{array}{c}\text { Tanah Rekah Estate- } \\
\text { Air Hitam }\end{array}$ & 16 & Rp. 547.000 & Rp. 8.752 .000 \\
\hline \multicolumn{3}{|c|}{ Biava Total } & Rp. 48.597.000 \\
\hline
\end{tabular}

Output Module Transportation POM-5 biaya total dan jadwal pengiriman Tabel 18 berikut.

Tabel 17. Perhitungan Biaya Total dan Jalur Pengiriman Optimal

\begin{tabular}{|c|c|c|c|c|}
\hline From & To & Shipment & $\begin{array}{c}\text { Cost per } \\
\text { unit }\end{array}$ & Shipment cost \\
\hline $\begin{array}{l}\text { Talang } \\
\text { Petai } \\
\text { Estate }\end{array}$ & $\begin{array}{l}\text { Bunga } \\
\text { Tanjung }\end{array}$ & 23 & Rp.680;000 & Rp.15.640.000 \\
\hline $\begin{array}{l}\text { Talang } \\
\text { Petai } \\
\text { Estate }\end{array}$ & $\begin{array}{l}\text { Air } \\
\text { Bikuk }\end{array}$ & 11 & Rp.823.000 & Rp. $9,053,000$ \\
\hline $\begin{array}{l}\text { Sei Kiang } \\
\text { Estate }\end{array}$ & $\begin{array}{l}\text { Air } \\
\text { Bikuk }\end{array}$ & 4 & Rp.585.000 & Rp. 2.340 .000 \\
\hline $\begin{array}{l}\text { Sei Kiang } \\
\text { Estate }\end{array}$ & $\begin{array}{l}\text { Air } \\
\text { Hitam }\end{array}$ & 16 & Rp.680.000 & Rp.10.880.000 \\
\hline $\begin{array}{l}\text { Tanah } \\
\text { Rekah } \\
\text { Estate }\end{array}$ & $\begin{array}{l}\text { Muko- } \\
\text { Muko }\end{array}$ & 16 & Rp.357.000 & Rp.5.712.000 \\
\hline $\begin{array}{l}\text { Tanah } \\
\text { Rekah } \\
\text { Estate }\end{array}$ & $\begin{array}{l}\text { Air } \\
\text { Bikuk }\end{array}$ & 11 & Rp. 452000 & Rp.4.972.000 \\
\hline \multicolumn{4}{|c|}{ Biaya Total } & Rp.48.597.000 \\
\hline
\end{tabular}

Dengan demikian hasil optimal simplek Tabel 14., NWC Tabel 15, NWC-MODI Tabel 16. dan output module transportation pada POM 5 Tabel 17adalah sama yaitu Rp.48.597.000,-

\section{SIMPULAN}

Hasil optimal metode tabel transportasi NWC, optimisasi (NWC-MODI) sertaoutputPOM 5 pasa ModuleLinear Programming dan Module Transportation sama yaitu Rp.48,597.000,-Hasil optimal biaya transportasi Rp.48,597.000,- lebih rendah dibandingkanhasil perhtungan langsung yaitu Rp. 51.392.000,- atau terjadi penurunan biaya transportasi sebesar Rp. 2.795.000,- atau 5,44\% lebih tinggi dengan hasil penelitian yang dilakukan oleh Mustadin sebesar 3,66\%.Hasil optimal dengan total biaya sama tetapi kapasitas dan jalur pengiriman berbeda memberikan alternatif jalur pilihan sesuai kapasitas pengiriman yang dikehendaki PT. Agro Muko.

Peneliti yang tertarik dapat melakukan penelitian ulang dengan metode perhtungan NWC dioptimalkan dengan metode stepping stones, metode awal biaya sel minimal dioptimalkan dengan MODI dan stepping stones dan metode awal VAM dioptimalkan dengan MODI dan stepping stones menggunakan data empiris terakhir (2019) di PT. Agro Muko.

\section{REVERENS}

[1] I. W. Ardhyani, Mengoptimalkan Biaya Distribusi Pakan Ternak dengan menggunakan Metode Transportasi (Studi Kasus di PT. X Krian), Teknika Engineering and Sains Journal, No.2, Vol.1, 95-100. 2017.

[2] N. L. Azizah, M. Suryawinata. Aplikasi Metode Transportasi Dalam Optimasi Biaya Distribusi Beras Sejahtera Pada Perum Bulog Sub-Divre Sidoarjo, Jurnal Ilmiah :Soulmath, No.1, Vol. 6,15-23. 2018

[3] F. Hillier and G. J. Lieberman,.Introduction to Operations Research, Ed.7, McGraw-Hill, New York. 2001

[4] Mustadin, Optimalisasi Teknik Riset Operasional Untuk Penghematan Biaya Transportasi Pengiriman Buah Kelapa Sawit Dengan Metode North West Corner (Studi Kasus PT.Agro Muko). Jursima(Jurnal Sistem Informasi Dan Manajemen, Sekolah Tinggi Ilmu Manajemen Dan Komputer Gici - Batam, No.2, Vol.4,1-8, 2016

[5] A. S. Primadiarta dan F. A. Narto, Optimasi Distribusi Produk dengan Metode Transportasi Berdasarkan Permintaan Produk di PT. XYZ Surabaya, Prosiding SNST, Fakultas Teknologi Industri, Institut Teknologi Adhi Tama Surabaya, 1 Juni 2017

[6] Siswanto, Operation Research, Jilid 1I, Erlangga, Jakarta. 2006

[7] H. Taha, Operation Research An Introduction, Ed.8, Pearson Education Inc.,New Jersey. 2007

[8] Taylor dan W. Bernard, Introduction to Management Science, Eighth Edition, diterjemahkan oleh Chairul D Djalman, Vita Silvira, Yanivi S Bachtiar, Salemba Empat, Jakarta. 2005

[9] Taylor dan W. Bernard, Introduction to Management Science, Seventh Edition, diterjemahkan oleh Chairul 
D Djalman, Vita Silvira, Yanivi S Bachtiar, Salemba Empat, Jakarta. 2003.

[10] W. Winstone, Operation ResearchApplication and Algorithms, Ed. 4, Duxbury, Indiana University, USA. 2004.

[11] Y. A. S. Yahya, Solusi Optimum Model Transportasi Pada CV. Manurindo di Makassar, Skripsi, Jurusan Matematika Fakultas Sains dan Teknologim Universitas Islam Negeri Alauddin, Makassar. 2004

[12] M. Zulhijah, Pengoptimalan Biaya Distribusi Barang Dengan Menggunakan Metode Transportasi Pada PT. Yusindo Mitra Persada, 2017. 